\title{
新検査制度の本格運用に向けた大飯発電所の 対応状況について
}

関西電力 栘本 晋嗣

原子力規制検查の 2020 年 4 月からの本格運用に向け，これまでの試運用における事業者の 取り組み状況として, 特にパフォーマンスベース検查に対する対応状況およびマインドチェン ジの必要性を紹介する。今回の検査制度見直しの特徴の一つであるパフォーマンスベースの検 查への見直しは事業者としてもパフォーマンス向上への良い契機であると考えている。

KEYWORDS: ROP, Reactor Oversight Process, nuclear regulation inspection reform, CM, Configuration Management, SDP, Significance Determination Process, CAP, Corrective Action Program

\section{I ははじめに}

2020 年 4 月から本格運用が開始される原子力規制検査 に向けて, 18 年 10 月から各発電所にて試運用が実施さ れている。本稿では当社での試運用を踏まえた現状の課 題認識として, 特に「パフォーマンス」をキーワードとし た事業者のマインドチェンジに関する状況を紹介する。

本解説は日本原子力学会 2019 年秋の大会での発表予 稿 ${ }^{1)}$ に加筆・補足を行ったものである。

\section{II. 試運用フェーズ 1, 2 の当面の課題}

\section{1. パフォーマンスベースの検査}

新検査制度の特徵として, リスク情報を活用したパ フォーマンスベースの検査を志向しており, 規制庁検査 官がフリーアクセス (事業者に頼らずに事業者図書を確 認し，事業者エスコートなしで現場を観察)の仕組みに より，実際の事業者活動に原子力安全上の問題がないか どうか(パフォーマンス)を効果的に検査できるよう, 試 運用が実施されている2,3)。

・試運用フェーズ 1 (2018 年度) : 検査ガイド内容確定,

フリーアクセスの実践/習熟

・試運用フェーズ 2 (2019 年度上期) : 全プラントで 日常検査, 代表プラントでチーム検査

・試運用フェーズ 3(2019 年度下期)：フェーズ 2 を 継続し, チーム検査を可能なプラントで実施 なお, リスク情報活用の試運用の現状としては, 図書

Efforts at Ohi Power Station (KEPCO) for Introduction of Nuclear Regulation Inspection: Shinji Masumoto.

(2019年 12 月 25 日 受理)
や現場観察の検査対象選定において，事業者の PRA モ デルを活用して原子力安全の観点からリスクが高いもの を抽出する計画とされているが, 現状は事業者側の PRA モデルが整備途上であるプラントが多く，また，提 供済みの大飯発電所の PRA モデルについても規制庁で 内容確認中であることから，検査対象の選定は定性的な 判断によって安全系機器や系統が選定されている。

パフォーマンスベースの一つの観点としては事業者の パフォーマンスとして安全実績指標(パフォーマンス指 標，PI）を確認されるとともに, PI では確認できない範 囲を対象として「検査」により安全上の問題の有無を確認 される。検査ガイドは規制庁サイトで公表されており, 規制庁検査官が日常検査, チーム検査の 2 種類の方法に より, 事業者活動について確認(検査)がされることとな る。本格運用後はフリーアクセスの運用により検査官の 活動 (どの機器を検査しているか等)をその時点では基本 的には事業者は感知しない状況で検査が遂行される状況 となる。

現在の試運用フェーズ 2 までは, そのフリーアクセス の成立性確認(特に事業者図書の確認方法)に注力されて いる。その成立性の確認も必要ではあるものの，一方 で，実際の安全上の影響の有無を確認するという観点の パフォーマンスベースの検査の成立性や運用性も確認す べきである。現時点では，規制側と事業者の双方同席の 振り返り会議 (面談)において, 試運用の結果が共有さ れ，意見交換が実施されているものの，安全上の影響の 有無を確認するというパフォーマンスベースの観点から は，検査指摘となる新たな気付きなしという簡潔な内容 となっており，事業者意見としてもフリーアクセスの運 
表 1 現行検查との比較(発電用原子炬施設)

\begin{tabular}{|c|c|c|}
\hline 実施者 & 現行 & 2020 年 4 月以降 \\
\hline \multirow{6}{*}{ 国 } & 保安検査 & \multirow{4}{*}{$\begin{array}{l}\text { 原子力規制検査 } \\
\text { ・検査に合格しないと使えな } \\
\text { いという強制力はなし。(米 } \\
\text { 国の検査制度 : ROP と同じ) }\end{array}$} \\
\hline & 施設定期検査 & \\
\hline & 定期安全管理審査 & \\
\hline & 溶接安全管理審査 & \\
\hline & 使用前検査 & \multirow{2}{*}{$\begin{array}{l}\text { 原子力規制検査 } \\
\text { ・確認を受けないと使えない } \\
\text { 強制力 (法定確認) は維持。 }\end{array}$} \\
\hline & 燃料体検査 & \\
\hline \multirow{3}{*}{ 業 } & 適合性確認検査 & 使用前事業者検査 \\
\hline & 溶接事業者検査 & 使用前事業者検査 \\
\hline & 定期事業者検査 & 定期事業者検査 \\
\hline
\end{tabular}

用に対する意見提示に留まることが多( ${ }^{4)}$ 。本来，制度 設計の観点からは, 制度の変更点を網羅的に確認するこ とで本格運用が円滑に進むように試運用期間を活用する ことが求められる。

試運用期間では, 特に米国の検查制度である ROP (Reactor Oversight Process：原子炉監視プロセス)を参 考とし，事業者側は自身が保証すべき原子力安全上のパ フォーマンスが何であるのかを明確化(見える化)し，検 查官はそれをどう確認したのか(確認できる見通しが得 られたのか)を共有することが理想的である。その際, 事 業者活動を従来からのコンプライアンスベースの視点の みの確認に留まったのか，あるいはパフォーマンスベー スの検査として事業者活動を確認し安全に影響を与える ようなパフォーマンスが十分に確認できたのか，換言す れば, 安全上の観点から事業者活動に不足がなかったの かを確認し，本格運用の円滑な開始に向けた共通認識を 醸成することが出来れば，有益な試運用になると考え る。現時点では, 事業者側からの意見提示(パフォーマン スの明確化の一助となる設計べースの提示や確認の質 疑)が不十分のため, 共通認識の䁔成には至っていない。 設計べース自体は，複数の図書(設置許可，工認，保安規 定, あるいは建設当時からの多くの社内資料等)に分散さ れた情報であり，また再稼働前の審査対応者やベテラン 社員等の知識や経験にも依存している情報である。設計 ベース図書 $(\mathrm{DBD})$ はこれらを体系的に整理して理解しや すくするための文書であり現在, 順次作成している途上 であるが，試運用に打いては仮の事例や過去事例等を題 材に議論することで, 検查指摘の重要度判断の相場観拀 よび検査対象とすべき事業者活動が何かという共通認識 を醸成することで有益な試運用になると考える。

\section{2. 試運用で醸成すべき事業者のマインドチェンジ}

事業者としては検查制度見直しの有無に関わらず，従 来から事故時に必要となる活動を含めてプラントの安 定・安全運転(パフォーマンス)を維持および向上させる ために継続的に活動している。一例としては事業者活動 を外部機関からレビュー(WANO, JANSI ピアレビュー や他電力の独立オーバーサイト)を受けて事業者のパ

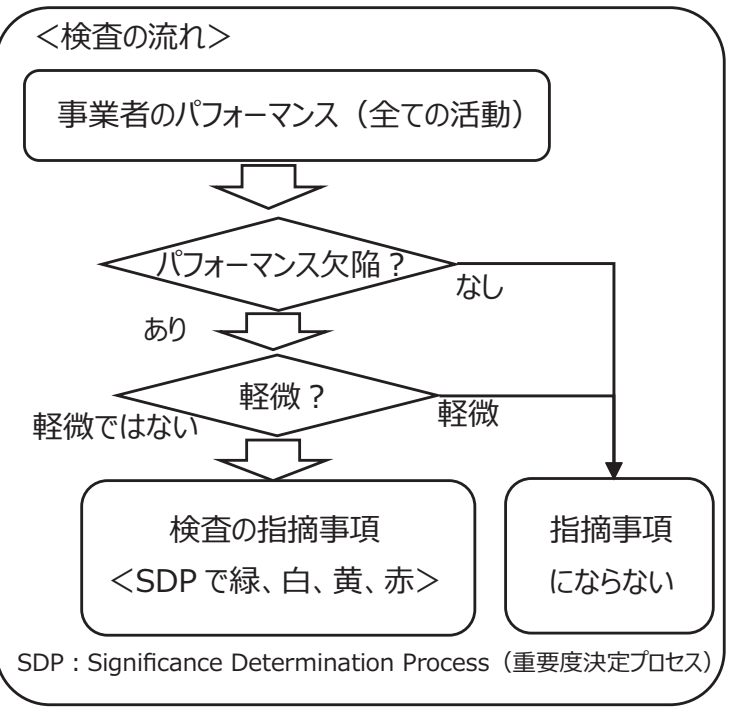

図 1 原子力規制検査の指摘事項抽出の概略フロー

フォーマンスを向上させる活動として，いわゆる世界の エクセレンスとの差分を埋める取り組みを行ってきてい る。また, 当社として CAP(是正処置活動)を見直して おり, 先例の米国事業者を手本として広く情報 $(\mathrm{CR}$, Condition Report)を収集し，プラントのパフォーマンス を改善させるための試運用を開始している。

一方で今回の原子力規制検查では, 原子力安全, 放射 線, 核物質防護の観点 $(7$ つの監視領域, いわゆる米国 ROP のコーナーストーン)を念頭において, 事業者が安 全上保証すべき状態が不足している場合(パフォーマン ス欠陥あり, かつ, マイナーを超える場合)に, 当該の事 業者活動の状態が検査の指摘事項となる。

原子力規制検查に打いて検査の指摘事項となる事象 は, パフォーマンス欠陥であって軽微を超えるものであ るが，パフォーマンス欠陥とは規制要求事項または事業 者の自主ルールに抵触している状態かつ予見拉よび予防 可能なものであり, 軽微を超えるものとは, 監視領域の 一つである原子力安全を例にすれば，プラントの事故等 が発生した時の停止操作 (炉心損傷防止, 格納容器破損防 止のための操作)が行えない状態等であれば指摘事項と なる。ここで重要な点は,「事故等が発生した時の状態」 を想定した場合において必要なパフォーマンスが発揮で きるかという点である。換言すれば, 非常用発電機 $(\mathrm{DG})$ や安全系ポンプ等の機器が「今」動作していることを確認 するだけではなく,「事故時等の状態で必要な性能を発揮 できるかどうか，いわゆるパフォーマンスが維持できて いるか」を常に自問自答することが重要であり，この点に おいて事業者のマインドチェンジが必要である。

例：『プラント運転中, 非常用 DG の月例定期試験に伴 い, DG 室の泠却ファンを起動したが,「冷却ファン風 量低」警報が発信。運転員が調査したところ, ファン の外気取入口が塗装作業用のシートで養生されてい 
た。警報発信から養生撤去まで数十分の短時間で完 了したため, DG の機能喪失はしておらずオペラブル であったと判断。今後の分析にも用いるため, 本事象 をCAPに登録した。』

この例の場合, 事業者として CAP に登録する際に考 慮すべき事項の例示を下記に挙げる。

・要求事項は何か。(この例では「ファンの風量」では なく,「DG 室の温度が一定以下」と考えられる)

- 夜間や週末の人手が少ない時間帯, あるいは最も過 酷な季節において LOCA 等が発生して DG の機能 が要求された場合にも同じように短時間で対応可能 か。

・機能喪失していない(オペラブルであった)と判断し た自身の技術的評価は妥当か。

・他の DG の待機状態は問題ないか。等

このように「要求事項」や「事故を想定した場合にもオ ペラブルであったと判断をしたこと」が分かる情報を CAP に登録しておくことで, 効率的にプラントのパ フォーマンスの把握が出来ると考える。

\section{III. 事業者における CAP 試運用}

\section{CAP によるパフォーマンスの理解状況}

当社は CAP 会議を従来から実施してきているが, 今 回の新検査制度に併せて, CAP 会議の見直しを行って おり, その特徴としては, 広く情報を収集し, 重要度に 応じた原因分析および是正処置を行うこととしている。

見直し版の CAP 会議として, 大飯発電所で 2018 年 10 月から社員を対象に開始し, 高浜および美浜発電所は 2019 年から開始し, 現在は 3 サイトともに協力会社から も情報収集するように対象を拡大して試運用を行ってい る。具体的には CAP システム試運用データベースを構 築し, CR (Condition Report)を CAP システム DB に入 力し, スクリーニング会議で安全への影響度 (CAQ 高/ 中/低, Non-CAQ)の分類案および処置担当課の割り当 て案を議論し，CAP 会議にて重要度および処置担当課 を決定する。スクリーニングメンバーの職位は品質保証 室(責任者), 発電室, 機械系および電気系の役職者であ り現在 6 名で試運用を行っている。'19 年 5 月末までの 大飯サイトでのスクリーニング実施件数は 2,600 件/8 か 月, $\mathrm{CAQ} / \mathrm{Non}-\mathrm{CAQ}$ 比は $1 / 50$ 程度であった。

今後の改善策は, 前述のように, 当該系統や設備に対 する要求事項は何か, それに反している状態および問題 は具体的に何か, 重要度を踏まえた処置期限になってい るか等の CAP 情報の記載を拡充していく。また，検査 官が直接 CAP システム DBへアクセスして検査対象を 選定すると想像しているが，米国同様にCAP の情報閲 覧のみで検査指摘の重要度が判定されることはなく, 事
表 2 米国事業者のスクリーニング要員の力量維持

\begin{tabular}{|c|c|}
\hline \multicolumn{2}{|r|}{ 事前確認資料(例) } \\
\hline $\begin{array}{l}\text { 社 } \\
\text { 内 } \\
\text { 資 } \\
\text { 料 }\end{array}$ & $\begin{array}{l}\text { パフォーマンス改善の実施, CAP 概要 (CAQ, Non- } \\
\mathrm{CAQ} \text { 分類), パフォーマンスの傾向監視, セルファセス } \\
\text { メント/ベンチマーキングのプロセス, 運転経験 }(\mathrm{OE}) \text { プ } \\
\text { ログラム, オペラビリティの決定と機能性の評価, 通知 } \\
\text { /報告性の評価, 保守規則プログラム 等 }\end{array}$ \\
\hline $\begin{array}{l}\text { 社 } \\
\text { 外 } \\
\text { 資 } \\
\text { 料 }\end{array}$ & $\begin{array}{l}\text { INPO-12-009 (ICES Reporting Requirements and } \\
\text { Standards), INPO 12-012(Traits of a Healthy Nuclear } \\
\text { Safety Culture), INPO 14-004 (Conduct of Performance } \\
\text { Improvement), NEI16-07 (Improving the Effectiveness } \\
\text { of Issue Resolution to Enhance Safety and Efficiency) }\end{array}$ \\
\hline $\begin{array}{l}\text { 法 } \\
\text { 令 }\end{array}$ & 10CFR 50 Appendix B(品質保証)等 \\
\hline
\end{tabular}

理解度確認の項目

1.CR 起票の閾值，2.オペラビリティ， 3. 報告の適切性，4. 保 守規則, 5. 即時の是正処置, 6. 重要度レベル，7. 評価レベル， 8.CAP/Non CAP の分類, 9. 経験に基づく傾向分析, 10. スク リーニング時の意見, 11. 責任者, 処置, 実施期限

業者への聞き取り等の事実確認も経て判定されるものと 考えている。

\section{2. 米国事業者の CAP スクリーニング要員の 養成例}

米国のある事業者はスクリーニング要員を社内資格制 度で管理および養成し，CAP スクリーニングのパ フォーマンスを一定に維持させているため, 参考に紹介 する。要員候補者は，事前に資料および関係法令を理解 し，実際のスクリーニングおよび CAP 会議を観察し， 先行有資格者との議論を経て, 役務の理解度を確認した 上で資格が付与される。理解度確認の項目で重要なもの は,「オペラビリティとは何か, また, それを維持してい るか」である。

\section{N． 事業者のパフォーマンス意識の向上}

\section{SDP 要員育成計画および実施状況}

一言で「パフォーマンス意識」と表現しているが,「維 持すべきパフォーマンスは何か」を意識, 理解するため に SDP (重要度決定プロセス)が活用できる。SDP 自体 は検査官が検査指摘となる可能性がある気付き事項(軽 微を超えると判断した事項)の重要度を判定する(緑白黄 赤の色判定する)ための簡易的かつ技術的評価ツールで ある。日本版 $\mathrm{SDP}\lceil$ 原子力規制検査における個別事項の 安全重要度評価プロセスに関するガイド」は米国 SDP (IMC609)を参考に作成されており，IMC609にはプラン 卜安全上の観点から管理が必須である項目が具体的に記 載されており, IMC609 の理解は事業者としても安全確 保のためのパフォーマンス向上のためにも得策である。

当社は '18 年度下期から米国 SDP (IMC609)を理解す るための教育を自主的に行っている。具体的には’18 年 度は本店の検查対応事務局 (6 名) が講師となり米国 
表 3 米国 SDP 事例の社内教育実績 (2018 年度)

\begin{tabular}{|c|c|c|}
\hline 米国事例 (件数) & $\begin{array}{l}\text { 米国 SDP } \\
\text { (IMC609 App.) }\end{array}$ & 米国の検査ガイド \\
\hline $\begin{array}{l}\text { 荒天前の不十分な } \\
\text { 点検他 }(7)\end{array}$ & $\begin{array}{l}\mathrm{A} \text { (運転中), } \\
\mathrm{M} \text { (定性的) }\end{array}$ & $\begin{array}{l}\text { IP71111.01 } \\
\text { 自然災害防護 }\end{array}$ \\
\hline $\begin{array}{l}\text { ISI 検査期間の不 } \\
\text { 適切な延長他 (3) }\end{array}$ & $\mathrm{A}$ & $\begin{array}{l}\text { IP71111.08 } \\
\text { 供用中検査 }\end{array}$ \\
\hline $\begin{array}{l}\text { 作業連絡不備で保 } \\
\text { 守時リスク評価せ } \\
\text { ず他(4) }\end{array}$ & K(保守リスク) & $\begin{array}{l}\text { IP71111.13 } \\
\text { メンテナンスリス } \\
\text { ク評価 }\end{array}$ \\
\hline $\begin{array}{l}\text { 溢水対策リストの } \\
\text { 漏れによる RHR } \\
\text { 機能喼失リスク増 } \\
\text { 加他 }(7)\end{array}$ & $\begin{array}{l}\text { A, } \\
\text { G(停止中) }\end{array}$ & $\begin{array}{l}\text { IP71111.15 } \\
\text { オペラビリティ判 } \\
\text { 断および性能評価 }\end{array}$ \\
\hline $\begin{array}{l}\mathrm{D} / \mathrm{G} \text { リレーの不適 } \\
\text { 切な保守他 }(3)\end{array}$ & $\begin{array}{l}A, \\
G\end{array}$ & $\begin{array}{l}\text { IP71111.19 } \\
\text { メンテナンス後試 } \\
\text { 験 }\end{array}$ \\
\hline $\begin{array}{l}\text { 弁の誤操作で SFP } \\
\text { 水位低下他 (4) }\end{array}$ & $\begin{array}{l}\mathrm{A}, \\
\mathrm{F}(\text { 火災防護 })\end{array}$ & $\begin{array}{l}\text { IP71111.20 } \\
\text { 停止中操作 }\end{array}$ \\
\hline $\begin{array}{l}\text { 不適切な放射線管 } \\
\text { 理による計画外の } \\
\text { 内部被ばく他 (4) }\end{array}$ & $\begin{array}{l}\mathrm{C}(\text { 従業員被ばく }), \\
\mathrm{D}(\text { 公衆被ばく })\end{array}$ & $\begin{array}{l}\text { IP71124.04 } \\
\text { 放 射 線 被ばく管 } \\
\text { 理, IP71124.06 } \\
\text { 放射性廃棄物管理 }\end{array}$ \\
\hline
\end{tabular}

$\mathrm{NRC}$ のウェブサイトに載っている検査報告書から指摘 事項の実例を抽出し, 試運用フェーズ 1 の分野に限定し て発電所の関係課(約 20 名 $/ 3$ サイト)に対し, 約 30 事例 の簡易な教育を実施した。

本年度('19 年度) は更なる充実方策として, 発電所に SDP 要員を育成すべく, 教育受講者を拡大 $($ 約 60 名/3 サイト)かつ明確化(責任者およびキーマンを選定)して 教育を開始している。

\section{2. コンフィグレーション管理の充実に向けた 一時的な構成変更管理の試運用}

発電所の運用においてコンフィグレーション管理のう ち, 一時的な構成変更 (TCC : Temporally Configuration Change)の管理も必要である。一時的な変更管理とは, 発電所の設計時(建設時)には明示的には考慮されていな い資機材, 仮設足場, 鉛遮へい, 計測器, ベント・ドレン ホース，車両等を発電所構内に一時的に設置する場合に も, 本設機器・配管等の機能 (設計ベース)を損なうこと がないように管理するものである。仮設足場について
は, 米国では NRC から注意喚起文書が発行され, 仮設足 場が安全系機器等に影響を与えないように管理すること を求めている5)。これら米国先行事例も参照しながら, 当社発電所のパフォーマンスを一定レベルに維持および 向上させるため, 既存手順書の見直しおよび新たな手順 書を制定し, 現在, 感度を高めて試運用を行っている。

\section{V.まとめ}

今回の検査制度見直しの特徵の一つであるパフォーマ ンスベースの検査への見直しは, 事業者としても原子力 安全(パフォーマンス)をより一層向上させる良い契機で ある。保証すべきパフォーマンスとして, 原子力安全, 放射線安全, 核物質防護の観点 (7つの監視領域)を念頭 に，事故の発生防止および事故時に発揮すべき原子力安 全の性能を維持し, 平常時の被ばく量を低減し, 核セ キュリティ対策を確実に行うことが重要である。ここ で，「実際のパフォーマンスに問題がないか」を常に自問 自答するマインドチェンジが必要であり，先行する米国 事業者の実例も参考にしながら，原子力規制検査の本格 運用の円滑な開始および運用定着に向けた改善活動を継 続的に実施していく。

$$
\text { - 参考資料 - }
$$

1）日本原子力学会 2019 年秋の大会 予稿 3O-PL01.

2) 検查制度見直しに関する試運用実施のための説明会資料,原 子力規制庁, 平成 30 年 8 月 20 日.

3）検査制度の見直しに関する試運用実施のための説明会資料 (フェーズ 2), 原子力規制庁, 平成 31 年 2 月 5 日.

4）検査制度見直しに関する関西電力株式会社との試運用に関 する面談 議事要旨，原子力規制庁，令和元年 5 月 8，9，14 日, 6 月 4 日他.

5) NRC Information Notice (IN 2007-29, Temporary Scaffolding Affects Operability of Safety- related Equipment), NRC, 2007 年.

\section{著者紹介}

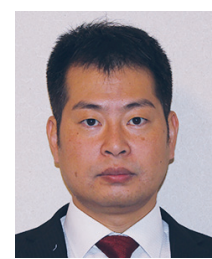
栘本晋嗣（ますもと・しんじ） 関西電力株式会社 原子力事業本部 発電グループ (専門分野/関心分野) 機械工学, 新検査 制度見直し対応 